\title{
Turkish Consumer Purchasing Decisions Regarding PGI-labelled Erzurum Civil Cheese
}

\begin{tabular}{|c|c|}
\hline \multicolumn{2}{|r|}{ Accepted/Kabul Tarihi:08.11.2017 } \\
\hline Research / Araştırma & \\
\hline $\begin{array}{l}\text { Received / Geliş Tarihi } \\
13.10 .2017\end{array}$ & Yavuz TOPCU*, Vedat DAĞDEMİR \\
\hline $\begin{array}{l}\text { Accepted / Kabul Tarih } \\
\text { 08.11.2017 }\end{array}$ & $\begin{array}{c}\text { Atatürk University, Faculty of Agriculture, Department of Agricultural } \\
\text { Economics, Erzurum- Turkey }\end{array}$ \\
\hline $\begin{array}{l}\text { DOI } \\
\text { 10.28955/alinterizbd.343725 }\end{array}$ & *e-mail: yavuztopcu@atauni.edu.tr \\
\hline $\begin{array}{l}\text { ISSN } 2564-7814 \\
\text { e-ISSN } 2587-2249\end{array}$ & \\
\hline
\end{tabular}

Abstract: The aim of the study is to explore how important intrinsic and extrinsic product attributes affect the way that the consumer decides whether to purchase Erzurum Civil cheese labelled with a Protected Geographical Indication (PGI). Data were obtained from a face-toface survey conducted with a sample of households in Erzurum during the autumn of 2014. Principal Component Analysis (PCA) was used to identify the main factors underlying the way that product attitudes and their socioeconomic characteristics influence the consumer's decision to purchase Erzurum Civil cheese. In addition, a k-means cluster analysis was applied to segment homogeneous consumer masses according to the main factors and their consumption frequencies. This was followed by a multiple regression analysis, which identified how these factors influence consumption volumes. The results of the study showed clearly that heavy users were motivated to buy Erzurum Civil cheese based on its intrinsic product attributes. Medium and light users, however, were motivated to buy the cheese as a result of its extrinsic product attributes, paying much more attention to product images of the cheese. If these positive motivation stimuli are combined, marketing tactics and strategies could increase demand trends for the redesigned and improved Erzurum Civil cheese and maximise consumer satisfaction in each cluster.

Keywords: Erzurum Civil Cheese, principal component analysis, k-means cluster analysis, multiple regression analysis, intrinsic and extrinsic product attributes

\section{Coğrafi İşaretli Erzurum Civil Peyniri İle İlgili Türk Tüketicilerin Satın Alma Kararları}

Öz: Çalışmanın amacı; Türk tüketicilerin bir coğrafi işaret (PGI) ile etiketlenmiş Erzurum Civil peyniri satın alıp almayacaklarına karar verme yöntemlerini, içsel ve dışsal ürün niteliklerinin nasıl etkilediğini ortaya koymaktır. Mevcut veriler 2014 yılı sonbaharı boyunca Erzurum'da örnek hane halkları ile yüz yüze yürütülen bir anketten elde edilmiştir. Temel Bileşenler Analizi (PCA), tüketicilerin Erzurum Civil Peyniri satın alma kararlarını etkileyen ürün nitelikleri ve onların sosyoekonomik özelliklerine işaret eden temel faktörleri belirlemek için kullanılmıştır. Aynı zamanda k-means kümeleme analizi, temel faktörler ve tüketicilerin tüketim frekanslarına göre homojen tüketici segmentleri oluşturmak için uygulanmıştır. Bu analiz, mevcut faktörlerin tüketim hacimlerini nasıl etkilediğini belirleyen çoklu regresyon analizleri ile takip edilmiştir. Araştırmanın sonuçları; yoğun kullanıcıların satına alma kararlarının Erzurum Civil peynirinin içsel nitelikleri tarafından motive edildiğini açık bir şekilde ortaya koymuştur. Fakat ılımlı ve düşük düzeyde kullanıcılar, ürünün dışsal niteliklerinin ve peynirin ürün imajına daha çok önem atfetmenin bir sonucu olarak satın almaya motive olmuşlardır. Bu pozitif motivasyon uyarıcıları birleştirilirse, pazarlama taktik ve stratejileri yeni dizayn edilmiş ve iyileştirilmiş Erzurum Civil peynirinin talep trenlerini artırabilir ve her bir kümedeki tüketim memnuniyetlerini maksimum kılabilir.

Anahtar Kelimeler: Erzurum Civil Peyniri, temel bileşenler analizi, k-ortalamalar kümeleme analizi, çoklu regresyon analizi, içsel ve dişsal ürün nitelikleri, 


\section{INTRODUCTION}

In recent years, drought and climatological changes based on global warming together with negative effects on flora and fauna resulting from contamination by chemical residues have led to increasing changes within the current agro-food production system. As a result, there is a tendency for farmers to move towards organic food production systems with PGI, PDO and Traditional Speciality Guaranteed (TSG) brand designations. In addition, direct marketing approaches or Short Food Supply Chains (SFSC) have been adopted to meet consumer demand more effectively and to increase farmers' annual activity income by producing higher value-added dairy products such as Erzurum Civil and Kuflu (mould-ripened, it an acid curd cheese with rennet added, is a popular local cheese variety with Erzurum of the origin in Turkey, and is commonly produced in Erzurum located at the eastern Anatolian region of Turkey. Erzurum civil cheese is produced in the small farms for their needs and also by small dairy plants for commercial purposes in Erzurum. This product is consumed as fresh cheese and/or the moldy cheese (kuflu cheese) ripened with the addition of curd by people living in this region during all the year (Yildiz et al., 2010) cheeses as well as Kars Cheddar, Erzincan Tulum, Van Herby and Feta cheese. In response to changes in the dairy product supply chain, consumer socioeconomic characteristics have been explored both with regard to intrinsic product attributes, including sensory quality after consumption, and extrinsic product attributes, which cover the marketing mix at the sales point.

During the last decade, Turkish consumers have increasingly turned to dairy product varieties with PGI, PDO and TSG branding. Their support for food confidence has had a big effect on consumer purchasing decisions. One example is Erzurum Civil cheese, a traditional local dairy product that has been given PGI status in Turkey. In 2007, the cheese was introduced to national food markets with redesigned images advertising these local brand designations (TPE, 2016). At the same time as the Turkish consumer's purchasing decisions about this product have changed, new marketing strategies have been designed to maximise product differentiation in the marketing mix by considering the relationships between customers' socioeconomic characteristics and their satisfaction with the intrinsic and extrinsic quality attributes that reflect actual product profiles in different retailers.

Analysis of Turkish consumer purchasing patterns, therefore, should focus on how these factors affect their purchasing attitudes and behaviours towards this product. These factors should underpin any product redesign or improvement. In addition, the effective implementation of marketing tactics and strategies for farmers, manufacturers and marketers should use information obtained from target misses and the results of product analyses. In this way, consumer satisfaction could be improved, while suppliers could also increase their annual revenue due to the increased demand for higher valueadded products.

Dairy products are an indispensable component of a healthy and balanced diet at all the stages of human life as calcium and other nutrients are required for a strong and robust skeletal and muscular system (Uzundumlu and Topcu, 2016). Consumption of dairy products has increased considerably throughout the world in recent years due to the benefits of dairy products for human health. The average per capita annual consumption of dairy products (such as cheese, milk and butter) were 20 and $25 \mathrm{~kg}, 28$ and 15 litres, and 1.3 and $3 \mathrm{~kg}$ in Turkey and Erzurum, respectively. These levels are much lower than those of countries that traditionally consume more cheese $(30 \mathrm{~kg}, 110$ litres, and 4.7 kg, respectively) (ASUD, 2010; TEPGE, 2012; Topcu, 2012).

To obtain a substantial increase in annual cheese consumption among Turkish consumers, traditional sensory analysis should be combined with modern market research methods aimed at developing an approach that integrates the evaluation of intrinsic and extrinsic cheese attributes, consumers' socioeconomic characteristics and the possible interactions between these factors. If suppliers are able to understand the relative importance of the influence of intrinsic and extrinsic attributes on consumer purchasing decisions and buying priorities at the retailer level, they will be able to improve customer satisfaction by redesigning and improving their current products. This study has focused on an integrated approach, which combines all the factors that influence Turkish consumers to buy cheese according to its region of origin. It should therefore provide an important contribution to the scientific literature by filling an important gap.

Cheese manufactured by processing organic milk obtained from dairy farms that are located in the high mountainous areas of the research region far and from intensive chemical pollutants has a relative superiority. This is based on important intrinsic attributes such as sensory and visual quality, and nutritional value (Lim et al., 2014; Grunert et al., 2015; Topcu, 2015; Topcu et al., 2015) together 
with extrinsic attributes, such as the region of origin, the actual product image, the cost to the consumer, the organic production type, price and ingredient information and the customer's income and expenditure (Marcoz et al., 2014; Chamorro et al., 2015; Munoz et al., 2015; Uzundumlu and Topcu, 2016). This cheese is therefore much preferred both by Turkish consumers who live in the eastern Anatolian region and throughout the country.

Deciding how intrinsic and extrinsic product attributes affect the decision to buy Erzurum Civil cheese with PGI branding, which provides a guarantee of attributes such as food and health safety, the region of origin, production and processing techniques, is important for the development of effective marketing tactics and strategies. This study, therefore, sought to find a solution to this problem. The aim of the study was to explore which intrinsic and extrinsic product attributes of PGI-branded Erzurum Civil cheese has the most influence on the purchasing decisions of Turkish consumers. The study then aimed to determine the relationship between the main product attributes and customers' socioeconomic characteristics in terms of motivating consumption.

\section{MATERIAL AND METHODS}

\section{Materials}

The primary data used in this study were obtained from a face-to-face survey exploring Turkish consumers' attitudes and behaviours about buying PGI-branded Erzurum Civil cheese. The survey took place between the autumn and winter of 2014.

\section{Methods}

\section{Sampling procedure}

In order to calculate the sample size for each district, the following formula was used (Topcu et al., 2009):

$n=\frac{Z^{2} * p^{*}(1-p)}{c^{2}}=385$

where in formul $1 ; \mathrm{n}=$ sample size; $\mathrm{Z}=\mathrm{z}$ value $(1.96$ for $95 \%$ confidence level $) ; \mathrm{p}=$ the percentage making a choice ( 0.5 used for sample size needed); and $\mathrm{c}=$ the deviation proportion between the main and sample population $(0.05= \pm 5)$.

The minimum sample size representing the main population, based on the population of each district, was calculated as 385 households. However, 400 households were interviewed to increase the representative nature of the sample. The weighted sample size and distribution of the survey for each district were determined proportionally (Table 1). Some characteristics of the main population and the three districts are also indicated in Table 1. 
Table 1. Some demographic characteristics of Erzurum Central Districts and Erzurum population, and the number of households and questionnaires

\begin{tabular}{|c|c|c|c|c|c|c|}
\hline \multirow{2}{*}{\multicolumn{3}{|c|}{ Demographic characteristics }} & \multicolumn{3}{|c|}{ Erzurum Central Districts } & \multirow{2}{*}{ Erzurum } \\
\hline & & & Yakutiye & Palandoken & Aziziye & \\
\hline \multirow{6}{*}{ ฮัల } & \multirow{2}{*}{ Male } & $\mathbf{N}$ & 92.976 & 82.177 & 26.095 & 384.356 \\
\hline & & $\%$ & 50.55 & 50.06 & 50.57 & 50.35 \\
\hline & \multirow{2}{*}{ Female } & $\mathbf{N}$ & 90.956 & 81.969 & 25.510 & 378.964 \\
\hline & & $\%$ & 49.45 & 49.94 & 49.43 & 49.65 \\
\hline & \multirow{2}{*}{ Total } & $\mathbf{N}$ & 183.932 & 164.146 & 51.605 & 763.320 \\
\hline & & $\%$ & 100.00 & 100.00 & 100.00 & 100.00 \\
\hline \multirow{8}{*}{ 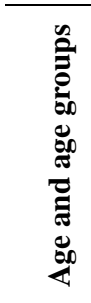 } & \multirow{2}{*}{$\begin{array}{l}\text { Child population } \\
(+<14 \text { years })\end{array}$} & $\mathbf{N}$ & 48.742 & 44.436 & 14.707 & 213.824 \\
\hline & & $\%$ & 26.50 & 27.07 & 28.50 & 28.00 \\
\hline & \multirow{2}{*}{$\begin{array}{l}\text { Young and mature } \\
(15-65 \text { years })\end{array}$} & $\mathbf{N}$ & 122.315 & 110.424 & 34.346 & 488.465 \\
\hline & & $\%$ & 66.50 & 67.27 & 66.75 & 64.00 \\
\hline & \multirow{2}{*}{$\begin{array}{l}\text { Old population } \\
(+>65 \text { years })\end{array}$} & $\mathbf{N}$ & 12.875 & 9.286 & 2.552 & 61.031 \\
\hline & & $\%$ & 7.00 & 5.66 & 4.75 & 8.00 \\
\hline & \multirow{2}{*}{ Total } & $\mathbf{N}$ & 183.932 & 164.146 & 51.605 & 763.320 \\
\hline & & $\%$ & 100.00 & 100.00 & 100.00 & 100.00 \\
\hline \multirow{3}{*}{\multicolumn{2}{|c|}{ Households }} & $\mathbf{N}$ & 43.793 & 38.174 & 11.468 & 145.394 \\
\hline & & $\overline{\boldsymbol{x}}$ & 4.20 & 4.30 & 4.50 & 5.25 \\
\hline & & $\%$ & 30.12 & 26.25 & 7.90 & 100.00 \\
\hline \multirow{2}{*}{\multicolumn{3}{|c|}{ \# Household \& questionnaires }} & \multicolumn{3}{|c|}{ Erzurum Central Districts } & \\
\hline & & & Yakutiye & Palandoken & Aziziye & Total \\
\hline \multirow{2}{*}{\multicolumn{2}{|c|}{ Households }} & $\mathbf{N}$ & 43.793 & 38.174 & 11.468 & 93.435 \\
\hline & & $\%$ & 46.87 & 40.86 & 12.27 & 100.00 \\
\hline \multirow{3}{*}{\multicolumn{2}{|c|}{$\begin{array}{l}\text { Main } \\
\text { Additional } \\
\text { Total }\end{array}$}} & $\mathbf{N}$ & 181.00 & 157.00 & 47.00 & 385.00 \\
\hline & & $\mathbf{N}$ & 7.00 & 6.00 & 2.00 & 15.00 \\
\hline & & $\mathbf{N}$ & 188.00 & 163.00 & 49.00 & 400.00 \\
\hline
\end{tabular}

\section{Questionnaire preparation and data collection}

The survey was conducted in Erzurum in the eastern Anatolian region of Turkey. Participants representing household heads were asked to respond to each statement indicating the relative importance of different Erzurum Civil cheese attributes. The questionnaire used a Likert format with a 1 to 5 scale (where 1 and 5 refer to the least and most important/preferred attributes, respectively). Of 29 attributes, 14 were related to intrinsic product attributes (sensory quality, food safety, nutritional value, etc.), whereas 15 were associated with extrinsic attributes (actual product quality, promotion mix, visual quality, region of origin, brand image, etc.) (Topcu et al., 2009; Topcu, 2015). In addition, the survey gathered information about the consumers' socioeconomic characteristics such as the amounts of Erzurum Civil cheese consumed versus a substitution cheese, price and consumption frequency, income and expenditure levels, and age and family size.

\section{Statistical analysis}

After editing and coding, the data were first subjected to PCA (a factor extraction method used to form uncorrelated linear combinations of the observed variables. The first component has the maximum variance. Successive components explain progressively smaller portions of the variance and are all uncorrelated with each other. PCA is used to obtain the initial factor solution. It can be used when there is a single correlation matrix.)to determine how the main factors relating to product attributes and socioeconomic characteristics influenced consumer decisions to buy Erzurum Civil cheese. PCA is a data reduction technique, which reduces the number of variables used in an analysis by creating new variables that combine redundancy in the data (SPSS 20.0, 2015). The first step in PCA is to determine the number of relevant factors. The study used the Varimax Rotation Method $(\mathrm{VRM})($ this method is an orthogonal rotation method that minimizes the number of variables that have high loading on each factor. It simplifies the interpretation of the factors.) to calculate this. PCA was used first to identify underlying aspects that were able to explain a correlation between a set of food product attributes and socioeconomic characteristics. The purpose of the PCA was to identify those attributes that accounted for a relatively large proportion of the variance in the sample.

In the next step, a k-means cluster analysis was used to identify three different homogeneous consumer segments: heavy (everyday), medium (weekly) and light (monthly) users with 133, 162 and 
105 individuals, respectively, according to the frequency with which they consumed Erzurum Civil Alinteri cheese.

In the final stage of the statistical analyses, the main factors obtained from the PCA were used in Multiple Regression and Multiple Correlation Analyses (MRC), respectively. MRC analysis was used to measure the efficiency of the main factors with regard to how the product attributes and socioeconomic characteristics influenced the amounts of cheese consumed. The coefficient estimates were estimated by using Ordinary Least Squares (OLS) analysis. The individual and group significance of these coefficients were tested using $t$ and $F$ tests, respectively. In order to evaluate any econometrical problems among the variables, the results were tested for overall multi-collinearity and auto-correlation problems by considering the Variance-inflating Factor (VIF) and Durbin-Watson d statistics (Gujarati, 2005; SPSS 20.0, 2015).

The MRC model could be written as following equation:

FMCONS $=f(A C T Q L T$, PROMIX, FODSFT , SENQLT , VISQLT, BRDIMG, NUTVAL, REGORG, DISINC,

SUBCON, SUBPRI, FAMLIF , $\left.\varepsilon_{i}\right)$

Dependent variable

CVLCON : Monthly Erzurum Civil cheese consumption amount (kg)

Independent variables

ACTQLT : Actual cheese quality (extrinsic attribute)

PROMIX : Promotion mix (extrinsic attributes)

FODSFT : Food safety (intrinsic attributes)

SENQLT : Sensory quality (intrinsic attribute)

VISQLT : Visual quality (extrinsic attribute)

BRDIMG : Brand image (extrinsic attribute)

NUTVAL : Nutritional value (intrinsic attributes)

REGORG : Region of origin (extrinsic attribute)

DISINC : Disposable income (\$)(socioeconomic factor)

SUBCON : Substitution cheese consumption (socioeconomic factor)

SUBPRI : Substitution cheese prices $(\$)$ (socioeconomic factor)

FAMLIF : Family life cycle (demographic factor)

\section{RESULTS AND DISCUSSION}

\section{Results of Principal Component Analysis (PCA)}

Kaiser normalisation (KMO), which compared partial correlation coefficients with observed coefficients including the influence of both the intrinsic and extrinsic attributes and consumer socioeconomic characteristics on Erzurum Civil cheese purchasing decisions was calculated as 0.87 and 0.64. This means that the data set for PCA was at perfect and good levels, respectively, as the test score was greater than 0.5 (Tables 2 and 3 ).

However, the chi-square value calculated to obtain Bartlett's test of Sphericity statistics for these factors was calculated as $3585.69(\mathrm{p}=0.000)$ and $611.07(\mathrm{p}=0.000)$. As a result, the unit matrix hypotheses were rejected $(\mathrm{p}<0.001)$. The VRM grouped the 29 and 10 variables related to the influence of the intrinsic and extrinsic attributes of Erzurum Civil cheese and consumers' socioeconomic characteristics on purchasing decisions into 8 and 4 (total 12) main factors with Eigen values greater than 1.0. These factors explained $65 \%$ and $66 \%$ of the total variances, respectively (Tables 2 and 3).

As shown in Table 2, the study found that actual quality (ACTQLT) and promotion mix (PROMIX), with a $21 \%$ share of the explained variance on consumers' decisions to buy Erzurum Civil cheese, were the most important extrinsic product attributes. Visual quality (VISQLT), brand image (BRDIMG) and the region of origin (REGORG) also had a $21 \%$ share of explained variance. 

Table 2. The results of $P C A$ with regard to the effects of food attributes on Erzurum Civil cheese purchase Alinteri
decisions of the consumers

\begin{tabular}{|c|c|c|c|c|c|c|c|c|}
\hline \multirow{2}{*}{$\begin{array}{c}\text { Factor } \\
\text { interpretations and } \\
\text { the variables }\end{array}$} & \multicolumn{8}{|c|}{ Factor loadings ${ }^{*}$} \\
\hline & F1 & $F 2$ & F3 & F4 & $F 5$ & F6 & F7 & F8 \\
\hline \multicolumn{9}{|c|}{ ACTUAL QUALITY (F1: ACTQLT) } \\
\hline Quality-price relation & 0.696 & 0.252 & 0.293 & 0.149 & 0.018 & -0.085 & 0.122 & -0.013 \\
\hline Core quality & 0.686 & 0.086 & 0.425 & 0.143 & 0.058 & 0.059 & 0.040 & -0.042 \\
\hline Cost to the consumer & 0.628 & 0.293 & 0.056 & -0.010 & 0.288 & -0.048 & 0.070 & 0.036 \\
\hline $\begin{array}{l}\text { Willingness to buy } \\
\text { organic cheese }\end{array}$ & 0.571 & 0.058 & 0.232 & 0.081 & 0.234 & 0.375 & 0.039 & 0.117 \\
\hline $\begin{array}{l}\text { Easily access to } \\
\text { cheese }\end{array}$ & 0.562 & 0.078 & 0.036 & 0.164 & 0.150 & 0.005 & 0.255 & 0.156 \\
\hline Stability in quality & 0.508 & 0.221 & 0.103 & 0.075 & 0.096 & 0.351 & 0.166 & -0.011 \\
\hline \multicolumn{9}{|c|}{ PROMOTION MIX (F2: PROMIX) } \\
\hline Promotion & 0.241 & 0.727 & 0.182 & 0.180 & -0.086 & -0.125 & -0.030 & 0.040 \\
\hline Advertisement & 0.041 & 0.724 & 0.114 & 0.022 & 0.039 & 0.329 & 0.015 & 0.007 \\
\hline Package weigh & 0.173 & 0.706 & 0.001 & 0.036 & 0.166 & 0.010 & 0.109 & 0.154 \\
\hline Package material & 0.144 & 0.556 & 0.084 & 0.056 & -0.130 & 0.362 & 0.056 & 0.096 \\
\hline $\begin{array}{l}\text { Package design and } \\
\text { appearance }\end{array}$ & 0.219 & 0.507 & 0.229 & -0.008 & 0.204 & 0.252 & 0.153 & 0.024 \\
\hline \multicolumn{9}{|c|}{ FOOD SAFETY (F3: FODSFT) } \\
\hline $\begin{array}{l}\text { Hygienic manufac. } \\
\text { and marketing }\end{array}$ & 0.139 & 0.219 & 0.820 & 0.130 & 0.160 & 0.024 & 0.088 & 0.054 \\
\hline Food safety & 0.178 & 0.162 & 0.811 & 0.130 & 0.093 & 0.068 & 0.201 & 0.120 \\
\hline Trustworthiness & 0.392 & 0.015 & 0.615 & 0.219 & -0.044 & 0.148 & 0.221 & 0.150 \\
\hline $\begin{array}{l}\text { Free of the harmful } \\
\text { substances }\end{array}$ & 0.244 & 0.123 & 0.573 & 0.281 & 0.046 & 0.371 & -0.254 & 0.165 \\
\hline $\begin{array}{l}\text { Trust to } \\
\text { manufacturer }\end{array}$ & 0.358 & 0.175 & 0.550 & 0.250 & 0.034 & 0.392 & -0.236 & 0.221 \\
\hline \multicolumn{9}{|c|}{ SENSORY QUALITY (F4: SENQLT) } \\
\hline Aroma and taste & 0.108 & 0.051 & 0.149 & 0.830 & 0.085 & 0.033 & 0.086 & $0.022^{-}$ \\
\hline Texture & 0.242 & 0.075 & 0.108 & 0.826 & 0.083 & 0.059 & 0.093 & 0.048 \\
\hline $\begin{array}{l}\text { Smell/odor and } \\
\text { flavor }\end{array}$ & 0.093 & 0.033 & 0.182 & 0.747 & 0.287 & 0.047 & 0.045 & 0.071 \\
\hline \multicolumn{9}{|c|}{ VISUAL QUALITY (F5: VISQLT) } \\
\hline Fibrous structure & 0.122 & 0.014 & 0.079 & 0.096 & 0.759 & 0.121 & 0.175 & 0.040 \\
\hline $\begin{array}{l}\text { A different } \\
\text { appearance }\end{array}$ & 0.200 & 0.045 & 0.006 & 0.094 & 0.751 & 0.168 & -0.016 & 0.289 \\
\hline $\begin{array}{l}\text { The cheese color and } \\
\text { tenderness }\end{array}$ & 0.065 & 0.076 & 0.115 & 0.271 & 0.636 & -0.009 & 0.121 & 0.064 \\
\hline \multicolumn{9}{|c|}{ BRAND IMAGE (F6: BRDIMG) } \\
\hline $\begin{array}{l}\text { Willingness to buy } \\
\text { private label }\end{array}$ & 0.066 & 0.280 & -0.050 & -0.014 & 0.111 & 0.624 & 0.324 & 0.158 \\
\hline $\begin{array}{l}\text { Willingness to buy } \\
\text { manuf. brand }\end{array}$ & 0.097 & 0.231 & 0.121 & 0.008 & 0.187 & 0.578 & 0.398 & 0.028 \\
\hline $\begin{array}{l}\text { Willingness to buy } \\
\text { local-branded }\end{array}$ & 0.056 & 0.186 & 0.433 & 0.166 & 0.214 & 0.573 & -0.071 & 0.127 \\
\hline \multicolumn{9}{|c|}{ NUTRITIONAL VALUE (F7: NUTVAL) } \\
\hline Low fat level & 0.255 & 0.043 & 0.108 & 0.101 & 0.057 & 0.122 & 0.783 & 0.127 \\
\hline Rich in calcium & 0.170 & 0.080 & 0.119 & 0.124 & 0.187 & 0.111 & 0.750 & 0.119 \\
\hline $\begin{array}{l}\text { Rich in vitamin and } \\
\text { proteins }\end{array}$ & 0.092 & 0.170 & 0.216 & 0.054 & 0.079 & 0.135 & 0.732 & 0.027 \\
\hline \multicolumn{9}{|c|}{ REGION OF ORIGIN (F8: REGORG) } \\
\hline $\begin{array}{l}\text { Erzurum (region) } \\
\text { of origin }\end{array}$ & 0.059 & 0.030 & 0.083 & 0.034 & 0.086 & 0.098 & 0.120 & 0.827 \\
\hline Eigen-values & 3.393 & 3.132 & 3.004 & 2.513 & & 2.253 & 1.929 & 1.596 \\
\hline $\begin{array}{l}\text { Share of explained } \\
\text { variance }(\%)\end{array}$ & 10.946 & 10.103 & 9.691 & 8.107 & & 7.267 & 6.221 & 5.149 \\
\hline $\begin{array}{l}\text { Cumulative share of } \\
\text { that }(\%)\end{array}$ & 10.946 & 21.049 & 30.73938. & $8.847 \quad 46.79$ & & 54.059 & 60.280 & 65.429 \\
\hline KMO (Kaiser-Meyer- & Dlkin) stati & istic & & & & & & 0.873 \\
\hline $\begin{array}{l}\text { Bartlett's test of } \\
\text { Sphericity }\end{array}$ & & & & Chi - & - square $\left(\lambda^{2}\right.$ & $d f: 465)$ : & $5.69\rfloor($ & $0.000)$ \\
\hline
\end{tabular}


All the extrinsic product attributes therefore explained $42 \%$ of total variance. Intrinsic product attributes such as food safety (FODSFT), sensory quality (SENQLT) and nutritional value (NUTVAL) accounted for $24 \%$ of total variance. As a result, the extrinsic product attributes were found to be the most important.

The results of the study also indicated that the cumulative share of the explained variance of consumers' socioeconomic characteristics (disposable income (DISINC), substitution cheese consumption (SUBCON) and substitution cheese prices (SUBPRI)) were more important than their demographic characteristics with regard to Erzurum Civil cheese purchasing decisions (Table 3).

Table 3. The results of $P C A$ with regard to the effects of the consumers' socioeconomic characteristics on Erzurum Civil cheese purchase decisions

\begin{tabular}{|c|c|c|c|c|}
\hline \multirow{2}{*}{ Factor interpretations and the variables } & \multicolumn{4}{|c|}{ Factor loadings $^{*}$} \\
\hline & F9 & F10 & F11 & F12 \\
\hline \multicolumn{5}{|l|}{ DISPOSABLE INCOME (F9: DISINC) } \\
\hline Total expenditure & 0.928 & 0.025 & 0.065 & -0.067 \\
\hline Food expenditure & 0.872 & -0.013 & 0.011 & 0.012 \\
\hline Disposable income & 0.861 & 0.109 & 0.137 & -0.138 \\
\hline \multicolumn{5}{|c|}{ SUBSTITUTION CONSUMPTION (F10: SUBCON) } \\
\hline Cheddar cheese consumption amount & 0.009 & 0.858 & 0.094 & -0.031 \\
\hline White cheese consumption amount & 0.035 & 0.597 & -0.157 & 0.385 \\
\hline \multicolumn{5}{|l|}{ SUBSTITUTION PRICES (F11: SUBPRI) } \\
\hline The price of green/moldy cheese & -0.068 & -0.254 & 0.757 & 0.166 \\
\hline The price of white cheese & 0.181 & 0.187 & 0.685 & -0.111 \\
\hline The price of cheddar cheese & 0.176 & 0.464 & 0.504 & -0.242 \\
\hline \multicolumn{5}{|l|}{ FAMILY LIFECRCLY (F12:FAMLIF) } \\
\hline The age of the consumer & -0.017 & 0.146 & -0.106 & 0.776 \\
\hline The family size of the consumer & -0.115 & -0.068 & 0.083 & 0.701 \\
\hline Eigen-values & 2.448 & 1.446 & 1.372 & 1.364 \\
\hline Share of explained variance $(\%)$ & 24.476 & 14.460 & 13.721 & 13.642 \\
\hline Cumulative share of that $(\%)$ & 24.476 & 38.936 & 52.657 & 66.299 \\
\hline KMO (Kaiser-Meyer-Olkin) statistic & & \multirow{2}{*}{\multicolumn{3}{|c|}{$\mid \begin{array}{c}\mathbf{0 . 6 4 4} \\
\mid \text { Chi - square }\left(\lambda^{2}, d f: 45\right): 611.067 \mid(p: 0.000)\end{array}$}} \\
\hline Bartlett's test of Sphericity & & & & \\
\hline
\end{tabular}

${ }^{*}$ The bold numbers indicated the largest loading for each variable

\section{Results of Cluster Analysis}

The extrinsic and intrinsic product attributes and consumers' socioeconomic and demographic characteristics derived from the PCA and impacting on purchase decisions were distributed into three homogeneous consumers segments using a k-means cluster analysis, as shown in Table 4.

The results of the study show that heavy users paid attention to core benefits based on intrinsic product attributes with FODSFT, SENQLT, NUTVAL and REGORG affecting sensory quality and economic characteristics such as DISINC and SUBPRI. On the other hand, medium and light users focused on actual Erzurum Civil cheese images with regard to the extrinsic product attributes covering ACTQLT and VISQLT with REGORG, and BRDIMG with REGORG under PROMIX, by adapting substitution cheese consumption patterns according to FAMLIF. 
Table 4. Final cluster centre scores and the number of cases in each cluster.

\begin{tabular}{lccc}
\hline \multirow{2}{*}{ Main factors } & \multicolumn{3}{c}{ Clusters $^{*}$} \\
\cline { 2 - 4 } & Heavy users (C1) $^{* * *}$ & Medium users (C2) $^{* *}$ & Light users (C3) $^{* *}$ \\
\hline \hline ACTUAL QUALITY (ACTQLT) & -0.189 & $\mathbf{0 . 2 6 0}$ & -1.118 \\
PROMOTION MIX (PROMIX) & -0.635 & -0.104 & $\mathbf{0 . 2 4 3}$ \\
FOOD SAFETY (FODSFT) & $\mathbf{0 . 5 0 5}$ & -0.143 & -0.387 \\
SENSORY QUALITY (SENQLT) & $\mathbf{0 . 1 6 9}$ & -0.151 & -1.342 \\
VISUAL QUALITY (VISQLT) & -0.154 & $\mathbf{0 . 0 8 6}$ & -0.144 \\
BRAND IMAGE (BRDIMG) & -0.030 & -0.162 & $\mathbf{0 . 4 0 7}$ \\
NUTRITIONAL VALUE (NUTVAL) & $\mathbf{0 . 4 1 3}$ & -0.102 & -0.085 \\
REGION OF ORIGIN (REGORG) & $\mathbf{0 . 3 1 7}$ & $\mathbf{0 . 0 8 9}$ & $\mathbf{0 . 2 4 5}$ \\
DISPOSABLE INCOME (DISINC) & $\mathbf{0 . 8 1 4}$ & -0.342 & -0.060 \\
SUBSTITUTION CONSUMPTION & -0.205 & -0.040 & $\mathbf{0 . 2 6 8}$ \\
(SUBCON) & $\mathbf{0 . 3 4 0}$ & -0.005 & -0.850 \\
SUBSTITUTION PRICES(SUBPRI) & -0.788 & -0.008 & $\mathbf{0 . 3 0 0}$ \\
FAMILY LIFECYCLE (FAMLIF) & $\mathbf{1 3 3}$ & $\mathbf{1 6 2}$ & $\mathbf{1 0 5}$ \\
\hline Number of total cases in each cluster & $\mathbf{3 3 \%} \%$ & $\mathbf{4 1 \%}$ & $\mathbf{2 6 \%}$ \\
\% of total cases in each cluster & & &
\end{tabular}

*Bold and bold italic numbers indicate the highest and second high final cluster centre scores for each factor, respectively. ${ }^{* *}$ According to F statistics, the final cluster centre scores were found very importance $(\mathrm{p}<0.01)$

T*** The total number of the cases (n): 400

\section{Results of Multiple Regression and Correlation (MRC) Analyses}

The statistical analyses shown in Table 5 report VIF values of 1.06 and 2.47, indicating that scores between 1.00 and 2.50 determine the acceptable reference range. Durbin-Watson d statistics of 1.94 positioned between $\mathrm{d}_{\mathrm{u}}(1.96)$ and $4-\mathrm{d}_{\mathrm{u}}(1.68)$ suggested that there were no econometric problems for multi-collinearity and auto-correlation in the MRC model (Gujarati, 2005). According to these results, the data sets could be used directly for the MRC model.

The determination statistics, OLS estimates of the parameter confidents and other statistical measurements such as $F$ and $t$, collinearity and correlation matrix scores are shown in Table 5. The results of the MRC analysis indicate that the determination coefficient $\left(R^{2}\right)$ and adjusted $R^{2}$ was calculated as 0.59 and 0.52 in the MRC model. As a result, all the independent variables were able to explain more than $50 \%$ of the dependent variable.

Table 5. The measurement results of the $M R C$ analysis and some statistic tests

\begin{tabular}{|c|c|c|c|c|c|c|c|c|c|}
\hline \multirow{4}{*}{$\begin{array}{c}\mathrm{n}: 400 \\
\mathrm{~d}_{\mathrm{c}}: 1.943 \\
\text { Variables }\end{array}$} & \multicolumn{3}{|c|}{$\mathrm{R}^{2}: 0.587$} & \multicolumn{2}{|c|}{ Adj. $R^{2}: 0.515$} & \multicolumn{3}{|c|}{$\mathrm{F}_{\mathrm{c}(12 ; 388)}: 9.558^{* * * *}$} & \multirow[t]{3}{*}{$\overline{\mathrm{DW}}$} \\
\hline & \multirow{2}{*}{\multicolumn{4}{|c|}{ MRC model }} & \multirow{2}{*}{\multicolumn{2}{|c|}{$\begin{array}{l}\text { Collinearity } \\
\text { statistics }\end{array}$}} & \multirow{2}{*}{\multicolumn{2}{|c|}{ Correlations }} & \\
\hline & & & & & & & & & \\
\hline & ${ }^{\mathrm{a}}$ Coefficient & S.D & $\mathrm{t}_{\mathrm{c}}$-value & p-value & Tolerance & VIF & Zero-order & Partial & Part \\
\hline Constant & 14.164 & 3.568 & 3.970 & $0.000^{* * *}$ & - & - & - & - & - \\
\hline ACTQLT & 0.214 & 1.945 & 2.226 & $0.027^{* *}$ & 0.668 & 1.496 & 0.004 & 0.263 & 0.175 \\
\hline PROMIX & 0.477 & 2.587 & 2.212 & $0.037^{* *}$ & 0.442 & 2.372 & 0.361 & 0.412 & 0.310 \\
\hline FODSFT & 0.291 & 1.754 & 1.797 & $0.085^{*}$ & 0.749 & 1.335 & 0.063 & 0.344 & 0.252 \\
\hline SENQLT & 0.272 & 1.877 & 4.008 & $0.000^{* * * *}$ & 0.836 & 1.197 & 0.188 & 0.315 & 0.248 \\
\hline VISQLT & 0.215 & 1.593 & 2.337 & $0.022^{* *}$ & 0.709 & 1.410 & 0.416 & 0.271 & 0.181 \\
\hline BRDIMG & 0.194 & 2.106 & 1.651 & $0.100^{*}$ & 0.383 & 2.609 & 0.240 & 0.184 & 0.120 \\
\hline NUTVAL & 0.183 & 2.303 & 2.169 & $0.034^{* *}$ & 0.839 & 1.193 & 0.018 & 0.253 & 0.168 \\
\hline REGORG & 0.182 & 1.732 & 2.063 & $0.043^{* *}$ & 0.770 & 1.298 & 0.114 & 0.241 & 0.160 \\
\hline DISINC & 0.213 & 1.306 & 2.248 & $0.035^{* *}$ & 0.401 & 2.494 & 0.277 & 0.206 & 0.135 \\
\hline SUBCON & -0.353 & 1.549 & -4.100 & $0.000^{* * *}$ & 0.807 & 1.239 & -0.387 & -0.443 & -0.317 \\
\hline SUBPRI & 0.132 & 1.500 & 1.191 & $0.050^{* *}$ & 0.809 & 1.236 & 0.054 & 0.156 & 0.118 \\
\hline FAMLIF & 0.443 & 1.964 & 5.173 & $0.000^{* * * *}$ & 0.814 & 1.228 & 0.506 & 0.529 & 0.400 \\
\hline
\end{tabular}

The partial regression coefficients of all the independent variables that took t-statistics into consideration were found to be statistically meaningful ( $t_{c}(d f: 12 ; 0.001-0.10)$ ). The signs of their coefficients (with negative values in SUBCON and positive values in the others) were also consistent with the economic theories at these levels $(p=0.001-0.10)$. 
The results of the MRC analysis also highlighted that extrinsic product attributes, including PROMIX, VISQLT and ACTQLT, and BRDIMG and REGORG, had a much stronger $(\mathrm{p}<0.001-0.05)$ and more moderate effect $(\mathrm{p}<0.10)$, respectively, on the cheese purchasing decisions of Turkish consumers. However, intrinsic product attributes, such as SENQLT and NUTVAL and FODSFT had a strong $(\mathrm{p}<0.001-0.05)$ and moderate $(\mathrm{p}<0.10)$ impact, respectively. On the other hand, the impact of socioeconomic and demographic characteristics on cheese purchasing decisions (including DISINC, SUBCON, SUBPRI and FAMLIF) had a significant effect $(\mathrm{p}<0.001-0.05)$.

This study simultaneously evaluated all the main factors to determine how both the important intrinsic and extrinsic attributes of Erzurum Civil cheese and consumers' socioeconomic and demographic characteristics affect the purchasing decisions of homogeneous consumer segments (grouped as heavy, medium and light users according to their consumption frequencies). In this study, the results of the MRC also showed that all the main attributes derived from the PCA had a statistically significant impact on cheese purchasing decisions $(\mathrm{p}<0.001-0.10)$.

According to the results, when making purchase decisions, heavy users placed much higher importance on intrinsic product attributes with regard to food safety, sensory quality and nutritional value and also to the region of origin (PDO/PGI). There was a much closer relationship with intrinsic product attributes when taking disposable income and substitution cheese prices into account.

A number of studies on consumer purchasing decisions have shown that local dairy products with PDO and PGI branding are commonly equated with higher positive purchase motivation and willingness to pay due to their intrinsic quality attributes, being more natural, fresh, healthy and safe than conventional dairy products. Consumers, therefore, have been shown to pay particular attention to food safety in the decision to buy dairy products (generally local cheese varieties) in studies conducted by Bellows et al. (2010), Lalor et al. (2011), Tsourgiannis et al. (2011), Topcu and Uzundumlu (2012), Boniface et al. (2013), Topcu (2015), Aprile et al. (2016), Giampietri et al. (2016), Hsu et al. (2016) and Zhao et al. (2016).

In addition, consumers are reported to focus on sensory quality in locally produced cheeses (Enneking et al., 2007; Koutroulou and Tsourgiannis, 2011; Aquilanti et al., 2013; Goosen and Muller, 2014) and on nutritional values (Tsourgiannis et al., 2011; Goosen and Muller, 2014; Tsourgiannis et al., 2014; Almli et al., 2015; Miklavec et al., 2015; Topcu, 2015; Pinto et al., 2016). All these studies support the findings of the current study with regard to the impact of intrinsic product attributes on Erzurum Civil cheese purchasing decisions, with heavy users gaining increased satisfaction from core benefits.

The signs of their coefficients (with negative values in SUBCON and positive values in the others) were also consistent with the economic theories at these levels $(p=0.001-0.10)$. With regard to medium and light users, their purchasing decisions and cognitive perceptions were based on extrinsic product attributes. As a result, they appreciated actual product images, and actual and visual qualities with PGI/PDO branding in the promotion mix, according to family life cycle and willingness to consume substitution cheeses, respectively.

With regard to influences on consumer purchasing decisions regarding dairy products at the retailer level, previous studies have reported that the effect of extrinsic product attributes based on actual product images plays a major role. The results of a number of studies about brand image and region of origin have emphasised stronger relationships between consumers' purchasing intentions, consumption frequencies and extrinsic quality attributes at the point of sale (Enneking et al., 2007; Kokthi et al., 2014; Uzundumlu and Topcu, 2016; Weber et al., 2015; Bartsch et al., 2016). The same findings are true for studies regarding actual and visual qualities (Koutroulou and Tsourgiannis, 2011; Boniface et al., 2013; Cacciolatti et al., 2015; Topcu, 2015; Aprile et al., 2016; Pinto et al., 2016). These findings are also compatible with the results of this study, which shows that extrinsic dairy product attributes are crucial in the purchase decision-making process for medium and light users.

As mentioned earlier, the results of earlier studies have also suggested that promotion mixes linking brand image and actual product life cycle lead to significant increases in mass consumption trends by providing positive motivation for purchasing intentions (Chrysochou, 2010; Hawkes, 2010; Luca and Suggs, 2010; Steenhuis et al., 2011; Glanz et al., 2012; Nordfalt and Lange, 2013; Liang, 2016; Porral and Mangin, 2016). 
Other studies about local cheese varieties have revealed that consumers' socioeconomic and demographic characteristics, including substitution food prices, general and food-related household expenditure, the life cycle of the household, available income and region of origin (PDO, PGI, TSG), were the most important factors impacting on their purchasing decisions (Tsourgiannis et al., 2011; Meijers and Van Dam, 2012; Boniface et al., 2013; Kokthi et al., 2014; Weber et al., 2015; Silva et al., 2016).

\section{CONCLUSION}

This study was conducted to identify how important intrinsic and extrinsic product attributes affect the Turkish consumer's decision to buy Erzurum Civil cheese. Consumers were segmented into three consumers groups: heavy, medium and light users, according to their consumption frequencies, and with different socioeconomic and demographic characteristics.

The results of the study show that heavy users gained their satisfaction from the core benefits of the cheese, based on intrinsic product attributes including food safety and sensory and nutritional quality. When deciding to purchase Erzurum Civil cheese, medium and light users paid much more attention to the actual product images of Erzurum Civil cheese, based on extrinsic product attributes combining visual and actual quality with PGI/PDO branding in the promotion mix.

Although heavy users shaped their purchase patterns based on the intrinsic attributes of Erzurum Civil cheese, other types of user appreciated the actual product image, which emphasised the hedonic quality of the cheese at the point of sale. Therefore, the study recommends that suppliers should improve the intrinsic quality attributes of Erzurum Civil cheese for heavy users and redesign the actual product image for medium and light users, based on its extrinsic quality attributes. If these positive motivation stimuli are combined, such marketing tactics and strategies could increase demand trends for the redesigned and improved Erzurum Civil cheese and maximise consumer satisfaction in each cluster. Sellers could provide both increased consumer satisfaction and greater economic benefits for themselves and the retailers who play an active role in the food supply chain by improving marketing margins.

\section{REFERENCES}

Almli, V.L., Øvrum, A., Hersleth, M., Almøy, T. and Næs, T., 2015. Investigating individual preferences in rating and ranking conjoint experiments. Food Quality and Preference 39 (1): 28-39.

Aprile, M.C., Caputo, V. and Nayga, R.M., 2016. Consumers' prefences and attitudes towards local food products. Journal of Food Products Markating 22 (1): 19-42.

ASUD, 2010. Report of the dairy products in the world, Ankara. http://www.suthatti. com.tr/sut_raporu_envanteri.pdf (access time: 30 December, 2014).

Aquilanti, L., Santarelli, S., Babini, V., Osimani, A. and Clementi, F., 2013. Quality evaluation and discrimination of semi-hard and hard cheeses from the Marche region (Central Italy) using chemometric tolls. International Dairy Journal 29 (1): 42-52.

Bartsch, F., Diamantopoulos, A., Paparoidamis, N.G. and Chumpitaz, R., 2016. Global brand ownership: the mediating roles of consumer attitudes and brand identification. Journal of Business Research 69 (9): 3629-3635.

Bellows, A.C., Alcaraz, G.V. and Hallman, W.K., 2010. Gender and food, a study of attitudes in the USA towards organic, local, U.S. grown, and GM-free foods. Appetite 55 (1): 540-550.

Boniface, B., Umberger, W.J. and Stringer, R., 2013. Factors influencing consumption of dairy products: An exploratory study in Kota Kinabalu-Sabah, Malaysia. Journal of Agribusiness Marketing 6 (1): 14-36.

Cacciolatti, L.A., Garcia, C.C. and Kalantzakis, M., 2015. Traditional Food Products: The Effect of Consumers' Characteristics, Product Knowledge, and Perceived Value on Actual Purchase. Journal of International Food and Agribusiness Marketing 27 (3): 155-176.

Chamorro, A., Rubio, S. and Miranda, F.J., 2015. The region-of-origin effect on purchasing preferences: the case of a multiregional designation of origin. British Food Journal 117 (2): 820-839.

Chrysochou, P., 2010. Food health branding: the role of marketing mix elements and public discourse in conveying a healthy brand image. Journal of Marketing Communications 16 (1-2): 69-85.

Enneking, U., Neumann, C. and Henneberg, S., 2007. How important intrinsic and extrinsic product attributes affect purchase decision. Food Quality and Preference 18 (2): 133-138.

Giampietri, E., Finco, A. and Giudice, T., 2016. Exploring consumers' behavior towards short food supply chains. British Food Journal 118 (3): 697-713.

Glanz, K. Bader D.M. and Iyer, S., 2012. Retailer grocery store marketing strategies and obesity. American Journal of Preventive Medicine 42 (5): 503-512.

Goosen, C and Muller, M., 2014. Consumer acceptance of Cheddar cheese: Intrinsic, extrinsic and sociodemographic influences, MS Thesis, Stellenbosch University, Agricultural Management, South Africa.

Gujarati D.N., 2005. Basic Econometrics, Reference Publish: 33, p: 540, ISBN 975-7860-99-9, Istanbul, Turkey. 
Grunert, K.G., Loose, S.M., Zhou, Y. and Tinggaard, S., 2015. Extrinsic and intrinsic quality cues in Chinese consumers' purchase of pork ribs. Food Quality and Preference 42 (1): 37-47.

Hawkes, C., 2010. Invited commentary food packaging: the medium is the message. Public Health Nutrition 13 (2): 297-299.

Hsu, S.Y., Chang, C.C. and Lin, T.T., 2016. An analysis of purchase intentions towards organic food on health consciousness and food safety with/under structural equation modelling. British Food Journal 118 (1): 200-216.

Kokthi E., Limon, M.G. and Bermudez, I.V., 2014. Analyzing Albanian consumer preferences for origin using cluster analysis (the case of cheese). International Journal of Innovative Research in Science and Engineering 35 (2): 35-47.

Koutroulou, A. and Tsourgiannis, L., 2011. Factors affecting consumers' purchasing behavior towards local foods in Greece: The case of the prefecture of Xanthi. Scientific Bulletin-Economic Science 10 (2): 3447.

Lalor, F., Madden, C., McKenzie, K. and Wall, P.G., 2011. Health claims on foodstuffs: A focus group study of consumer attitudes. Journal of Functional Foods 3 (1): 56-59.

Liang, R., 2016. Predicting intentions to purchase organic food: the moderating effects of organic food prices. British Food Journal 118 (1): 183-199.

Lim, K.H., Hu, W., Maynard, L.J. and Goddard, E., 2014. A taste for safer beef? How much does consumers' perceived risk influence willingness to pay for country-of-origin labelled beef. Agribusiness 30 (1): 1730 .

Luca, N.R. and Suggs, L.S., 2010. Strategies for the social marketing mix: A systematic review. Social Marketing Quarterly 16 (4): 122-149.

Marcoz, E.M., Melewar, T.C. and Dennis, C., 2014. The value of region of origin, producer and protected designation of origin label for visitors and locals. International Journal of Tourism Research 16 (4): 313-328.

Meijers, M.H.C. and Van Dam, Y.K., 2012. Sustainable food purchases in the Netherlands: the influence of consumer characteristics. Journal on Chain and Network Science 12 (2): 181-198.

Miklavec, K., Pravst, I., Grunert, K.G., Klopčič, M. and Pohar, J., 2015. The influence of health claims and nutritional composition on consumers' yoghurt preferences. Food Quality and Preference 43 (1): $26-33$.

Munoz, C.X., Johnson, E.C., McKenzie, A.L., Guelinckx, I., Graverholt, G., Casa, D.J. and Armstrong, L.E., 2015. Habitual total water intake and dimensions of mood in healthy young women. Appetite 92 (1): 81-86.

Nordfalt, J. and Lange, F., 2013. In-store demonstrations as a promotion tool. Journal of Retailer and Consumer Services 20 (1): 20-25.

Pinto, V.R.A., Melo, L.F., Balbino, D.F., Novaes, J.F., Negrete, M.C. and Sousa, T.D., 2016. The evaluation of consumer behavior influence on the buying process of dairy products in Minas Gerais State, Brazil. Journal of Food and Nutrition Research 4 (1): 51-59.

Porral, C.C. and Mangin, J.P.L., 2016. Food private label brands: the role of consumer trust on loyalty and purchase intention. British Food Journal 118 (3): 679-713.

Silva, F.Q., Freire, O., Brandao, M.M., Isabella, G., Moreira, L.B., 2016. Intentions to purchase food through the internet: developing and testing a model. British Food Journal 118 (3): 572-587.

SPSS Base 20.0, 2015. SPSS Base 20.0 User's Guide, SPSS, Chicago, IL., pp.161-184.

Steenhuis, I.H.M., Waterlander, W.E. and Mul, A., 2011. Consumer food choice: the role of price and pricing strategies. Public Health Nutrition 14 (12): 2220-2226.

TEPGE, 2012. Forecasting report of dairy products, Ankara. http://www.tepge.gov.tr (access time: 15 February, 2014).

TPE, 2016. Food products with Protected Geographical Indications (PGI), Protected Designation of Origin (PDO) in Turkey Ankara. http://www.tpe.gov.tr (access time: 20 April, 2016).

Topcu, Y., Isik, H.B. and Uzundumlu, A.S., 2009. Turkish consumer attitudes toward food products: The case of Erzurum. Italian Journal of Food Science 21 (1): 37-50.

Topcu, Y., 2012. The effects of the local products on the rural development under societal marketing orientation: the case of Erzurum Civil cheese. $10^{\text {th }}$ National Agricultural Economics Congress, 5-7 September, Konya, Turkey, pp. 916-925.

Topcu, Y. and Uzundumlu, A.S., 2012. Turkish consumers' purchase attitude and behaviors towards Kahramanmaras type ice cream as a local branded product. African Journal of Business Management. 34 (6): 9695-9703.

Topcu, Y., 2015. Turkish consumer decisions affecting ice cream consumption. Italian Journal of Food Science 27 (1): 1-11.

Topcu, Y., Uzundumlu, A.S. and Baran, D., 2015. How sensory and hedonic quality attributes affect fresh red meat consumption decision of Turkish consumers? Italian Journal of Food Science 27 (2): 89-98.

Tsourgiannis, L., Karasavvoglou, A. and Florou, G., 2011. Consumers' attitudes towards GM Free products in a European Region. The case of the Prefecture of Drama-Kavala-Xanthi in Greece. Appetite 57 (1): 448 458. 
Tsourgiannis, L., Karasavvoglou, A., Tsourgiannis, C.A., Florou, G., Theodosiou, T. and Valsamidis, S., 2014. Factors affecting consumers in Greece to buy during the economic crisis period food produced domestically in Greece. Procedia Economics and Finance 9 (1): 439-455.

Uzundumlu, A.S. and Topcu, Y., 2016. Determining Turkish consumers' consumption satisfaction with Erzurum Civil cheese. British Food Journal 118 (4): 896-914.

Weber, M.J., Lambert, J.T., Kelley, A. and Jennings, S.S., 2015. Consumer ethnocentrism and tendencies to protect Wisconsin-made cheese products. International Academy of Marketing Studies Journal 19 (3): 149-168.

Yildiz, F., Yetisemeyen, A., Senel, E., Ozkaya, F., Oztekin, S. and Sanli, E., 2010. Some properties of Civil Cheese. International Journal of Dairy Technology 63 (4): 575-580.

Zhao, X., Kneafsey, M. and Finlay, D., 2016. Food safety and Chinese geographical indications. British Food Journal 118 (1): 217-230. 